Georgia State University

ScholarWorks @ Georgia State University

\title{
The Topsy-Turvy Sharing of the Gaming Tax Field in Canada, 1970-2010: Provincial Payments, Federal Withdrawal
}

\author{
Etienne Desjardins \\ Universite de Montreal \\ Melina Longpre \\ University of British Columbia \\ Francois Vaillancourt \\ Université de Montréal, francois.vaillancourt@umontreal.ca
}

Follow this and additional works at: https://scholarworks.gsu.edu/icepp

Part of the Economics Commons

\section{Recommended Citation}

Desjardins, Etienne; Longpre, Melina; and Vaillancourt, Francois, "The Topsy-Turvy Sharing of the Gaming Tax Field in Canada, 1970-2010: Provincial Payments, Federal Withdrawal" (2012). ICEPP Working Papers. 74.

https://scholarworks.gsu.edu/icepp/74

This Working Paper is brought to you for free and open access by the International Center for Public Policy at ScholarWorks @ Georgia State University. It has been accepted for inclusion in ICEPP Working Papers by an authorized administrator of ScholarWorks @ Georgia State University. For more information, please contact scholarworks@gsu.edu. 
International Center for Public Policy Working Paper 12-28

September 2012
The Topsy-Turvy Sharing of the Gaming Tax Field in Canada, 1970-2010: Provincial Payments, Federal Withdrawal

Étienne Desjardins

Mélina Longpré

François Vaillancourt 

International Center for Public Policy

Working Paper 12-28

\title{
The Topsy-Turvy Sharing of the Gaming Tax Field in Canada, 1970-2010: Provincial Payments, Federal Withdrawal
}

\author{
Étienne Desjardins \\ Mélina Longpré \\ François Vaillancourt
}

\section{September 2012}

International Center for Public Policy

Andrew Young School of Policy Studies

Georgia State University

Atlanta, Georgia 30303

United States of America

Phone: (404) 651-1144

Fax: (404) 651-4449

Email: hseraphin@gsu.edu

Internet: http://aysps.gsu.edu/isp/index.html

Copyright 2006, the Andrew Young School of Policy Studies, Georgia State University. No part of the material protected by this copyright notice may be reproduced or utilized in any form or by any means without prior written permission from the copyright owner. 


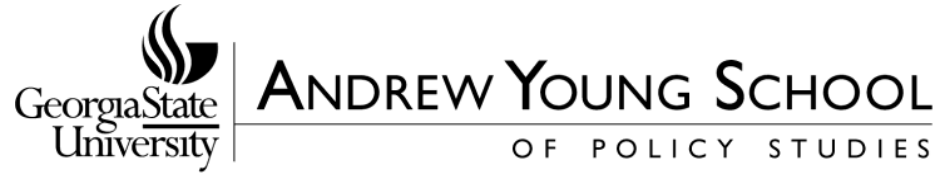

\section{International Center for Public Policy Andrew Young School of Policy Studies}

The Andrew Young School of Policy Studies was established at Georgia State University with the objective of promoting excellence in the design, implementation, and evaluation of public policy. In addition to two academic departments (economics and public administration), the Andrew Young School houses seven leading research centers and policy programs, including the International Center for Public Policy.

The mission of the International Center for Public Policy is to provide academic and professional training, applied research, and technical assistance in support of sound public policy and sustainable economic growth in developing and transitional economies.

The International Center for Public Policy at the Andrew Young School of Policy Studies is recognized worldwide for its efforts in support of economic and public policy reforms through technical assistance and training around the world. This reputation has been built serving a diverse client base, including the World Bank, the U.S. Agency for International Development (USAID), the United Nations Development Programme (UNDP), finance ministries, government organizations, legislative bodies and private sector institutions.

The success of the International Center for Public Policy reflects the breadth and depth of the in-house technical expertise that the International Center for Public Policy can draw upon. The Andrew Young School's faculty are leading experts in economics and public policy and have authored books, published in major academic and technical journals, and have extensive experience in designing and implementing technical assistance and training programs. Andrew Young School faculty have been active in policy reform in over 40 countries around the world. Our technical assistance strategy is not to merely provide technical prescriptions for policy reform, but to engage in a collaborative effort with the host government and donor agency to identify and analyze the issues at hand, arrive at policy solutions and implement reforms.

The International Center for Public Policy specializes in four broad policy areas:

- Fiscal policy, including tax reforms, public expenditure reviews, tax administration reform

- Fiscal decentralization, including fiscal decentralization reforms, design of intergovernmental transfer systems, urban government finance

- Budgeting and fiscal management, including local government budgeting, performancebased budgeting, capital budgeting, multi-year budgeting

- Economic analysis and revenue forecasting, including micro-simulation, time series forecasting,

For more information about our technical assistance activities and training programs, please visit our website at http://aysps.gsu.edu/isp/index.html or contact us by email at hseraphin@gsu.edu. 


\title{
The Topsy-Turvy Sharing of the Gaming Tax Field in Canada, 1970-2010: Provincial Payments, Federal Withdrawal
}

\author{
Étienne Desjardins*, Mélina Longpré** and François Vaillancourt*** \\ * BSc (Econ) Université de Montréal \\ ** MSc (Econ), University of British Columbia \\ *** Emeritus professor (Econ) Université de Montréal and Fellow, CIRANO
}

\begin{abstract}
This paper presents an unusual inter-governmental financial arrangement: a payment by constituent units of a federation to the federal government to keep it out of a fiscal field and thus gain sole occupancy for themselves. This paper thus presents the history of the federal/provincial relationship in the gaming field in Canada focusing on the key period of 1976-1980 when both levels of governments operated lotteries. It chronicles the attempts of both levels of governments to reach an agreement on their sharing of this revenue field. Revenue sharing was rejected, market slicing was agreed to but since 1980, the provinces have purchased a sole occupancy right through an annual payment to the federal government. It shows, using multivariate analysis, that the presence of Loto-Canada reduced provincial gaming revenues in 1978 and 1979 and thus that the provinces were right to seek sole occupancy of the lottery field. It also shows, using numerical simulations of alternative formulas, that the agreement negotiated is very advantageous for the provinces as it did not take into account either the future growth of the lottery market or the diversification of the gaming market in Canada from 1980 to 2010, let alone both.
\end{abstract}

Key words: Lottery, Gaming revenues, fiscal federalism, Canada 


\section{Introduction}

Canadian financial federal-provincial relations are characterized by various tax sharing agreements, federal per capita transfers, federally funded equalization payments and numerous federal-provincial cost-sharing agreements (Bird and Vaillancourt, 2007). All of these features are found in other federations in the world. However, the federal-provincial financial arrangements in the field of gaming appear to be unique to Canada. The provinces as a group pay the federal government who in return leaves the gaming field to the provincial tax monopolies, not introducing a national lottery. The purpose of this paper is to document and analyze this set of arrangements. This paper is divided in three parts: first, we present the history of the federal/provincial relationship in the gaming field with special attention to the birth and death (at the tender age of four) of the federal Loto-Canada, as well as the attempts to reach agreements with the provinces regarding the presence of the federal government as implemented by its lottery agency in the gaming field. Second, we present an estimation of the impact of Loto-Canada's presence on provincial gaming net revenues and ticket sales. Third, we simulate the federal revenues for the 1980-2010 period under alternative revenue sharing agreements and compare them to effective revenues.

\section{History of the Canadian federal/provincial relationship in the gaming fiscal field}

Gaming was legalized in Canada with an amendment to the criminal code ${ }^{1}$ in 1969 . This was partly due to the introduction in 1968 by the city of Montréal of a voluntary tax that allowed 'taxpayers' to win a prize and also to changing mores with respect to gaming which were increasing the demand for gaming, including illegal lotteries². The province of Québec was the first to enter the lottery market in 1970 with its own lottery corporation, LotoQuébec ${ }^{3}$. Ontario followed in 1975 with the Ontario Lottery Corporation, followed shortly

\footnotetext{
${ }^{1}$ In Canada, the criminal code is federal and applies in all provinces

${ }^{2}$ Of which the most common was the Irish sweepstakes

${ }^{3}$ The Montreal voluntary tax was thus replaced de facto by a provincial lottery. This is similar to what happened in the mid-sixties when the introduction of a provincial sales tax was accompanied with the demise of municipal and school board sales taxes
} 
after in 1976 by two four-province lottery bodies: the Atlantic Lottery Corporation ${ }^{4}$ and the Western Lottery Corporation ${ }^{5}$. An Olympic lottery was put in place in 1973 by the federal government to help finance the Montreal 1976 Olympic Games ${ }^{6}$. The Olympic lottery sold $\$ 10$ tickets with a $\$ 1$ million prize ${ }^{7}$. Loto-Canada was created in September 1976 by the federal government as a successor to the Olympic Lottery. Thus a permanent federal lottery was created once the ten provinces had already introduced provincial lotteries. ${ }^{8}$ While the Olympic lottery was originally the only one offering a $\$ 1$ million prize (for a $\$ 10$ ticket), by 1976 both the Ontario and Western Lottery corporations were offering an equivalent $\$ 1$ million prize for tickets sold for $\$ 5$. The sales of $\$ 10$ tickets subsequently plunged; thus Loto-Canada was forced to introduce new products to maintain its revenues in order to meet the federal commitment to help finance the Olympic Games deficit until 1979.

Throughout the 1976-1979 period, discussions took place between the federal government and the provinces concerning the sharing of the lottery field and thus revenues between the two levels of government after 1979. No progress had been made in the discussions between the federal and provincial governments when Loto-Canada decided to proceed with the implementation of a new product, Loto Select ${ }^{9}$, in 1978.

In 1978 federal-provincial discussions on revenue-sharing and federal transfers such as equalisation and block grants (Established program financing) were ongoing. The federal proposals included for the first time the sharing of federal lottery revenues. The approach suggested was the sharing of revenues according to the respective financial involvement of each level of government in the fields traditionally funded by lottery revenues, such as amateur sports. This would have meant that provincial governments would receive $50 \%$ of the net revenues of the federal lottery (in addition to the revenues from their own

\footnotetext{
${ }^{4}$ Made up of Newfoundland and Labrador, Prince Edward Island, Nova Scotia and New Brunswick

${ }^{5}$ Made up of Manitoba, Saskatchewan, Alberta, and British Columbia

${ }^{6}$ It raised money mainly for the Olympics but also for amateur sports $\mathrm{http} / / / \mathrm{www} \cdot$ thecanadianencyclopedia.com/articles/lottery

${ }^{7}$ Cousineau, Guy. Report on Loto Select, 1979, p. 2

${ }^{8}$ With 12.5 percent of its profits distributed to the provincial governments; the allocation key was the share of tickets sold in each province.

${ }^{9}$ As implied by its name, Loto Select would allow purchasers to choose the combination of numbers on their ticket. This was an innovative concept then.
} 
lotteries $)^{10}$. The provinces demanded the withdrawal of the federal government from the lottery field, stating they had no interest in such revenue-sharing. Therefore, this revenue sharing arrangement was not implemented. However, later in 1978 a new agreement was reached, providing that provinces would have the exclusive rights to games with a ticket price of $\$ 9$ or less, whereas the federal government would solely occupy the market of games with a ticket price of $\$ 10$ and above. This was already the practice since 1976 of the provincial and federal lotteries. Such an approach replaced revenue-sharing by marketslicing. Both federal and provincial governments were satisfied with the elimination of direct price competition: this fulfilled the desire for cooperation sought by the former, and the desire for exclusivity in a specific market by the latter. The grounds were thus laid for a Memorandum of Understanding on Lotteries between the federal government and the provinces ${ }^{11}$. However, important aspects of that agreement remained to be negotiated.

"This accord was contingent, however, on a commitment by the Ontario and Quebec lottery corporations to settle Loto-Canada's obligations in the lotto game (Loto-Select). This settlement proved to be more difficult than anticipated as the problem of integrating two different game systems became apparent. This realization tended to invalidate the previous understanding that one way to settle the Corporation's contract would be for the provincial lotteries simply to take over those portions of the system which were ready for delivery. It became clear that the best resolution could be a monetary settlement. This, however, meant further negotiations and a further period of uncertainty." 12

The agreement was thus never put in place. During this period, the preparation by LotoCanada for the implementation of Loto Select continued with a planned introduction date in November 1978.

Further federal-provincial negotiations led to the signature of a new Memorandum in October 1978, thus triggering the cancellation of Loto Select. The main features of this 1978 agreement are summarized in Appendix A-1. The abolition of Loto Select set the table for further cooperation between the federal government and the provinces. The payment by

\footnotetext{
${ }^{10}$ Cousineau, Guy, Report on Loto Select, 1979, p. 9

${ }^{11}$ Except Nova Scotia

${ }^{12}$ Cousineau, Guy, Report on Loto Select, 1979, p. 10
} 
the provinces of the termination costs of Loto Select could be seen as an investment leading to higher profits to be generated by an ongoing and unchallenged monopoly in a share of the lottery market.

In late 1978 and early 1979, Loto-Québec introduced its real time bet acceptation system, thus creating the instant lotteries field. Additionally, Ontario, Québec and the Western provinces jointly created the Interprovincial Lottery Corporation; the Atlantic Provinces joined a few months later. For the same ticket price, this consolidated market allowed more tickets to be sold and more grand prizes to be drawn, each draw offering ten one million dollar prizes. Loto-Canada attempted to counter these moves but this resulted in an increase in its expenses and a fall both in net revenues and ticket sales. These actions were disavowed by the federal Progressive Conservative party, then in opposition, which promised in its electoral program the dismantling of Loto-Canada. After coming to power following the February 1979 election, it carried out this promise.

The federal/provincial lottery agreement was signed in August 1979. The federal government granted the provinces a monopoly on lotteries in exchange for yearly payments of $\$ 24$ million from the provincial lottery corporations. These payments took the form of quarterly instalments of $\$ 6$ million beginning on April $1^{\text {st }} 1980$. They were to increase according to inflation using the Consumer Price Index as a measure. Every lottery corporation was to contribute to this payment proportionately to the revenues it gained as a percentage of the total Canadian revenues from lotteries.

In 1981, the federal government passed the Athletic contests and Events pool act which allowed the creation of the Canadian Sports pool corp. The provinces considered that this contravened the 1979 agreement. After discussions, the federal government did not implement a lottery to help finance the Calgary Olympic Games. In exchange, the provinces agreed to pay the federal government an extra $\$ 100$ million over three years to help finance that event. Thereafter, the criminal code was amended in December 1985 and the provision allowing the federal government to conduct lotteries was removed; the lottery fiscal field was now strictly reserved to the provinces. 


\section{The impact of the presence of Loto-Canada in the lottery field on the provincial gaming revenues: empirical results}

The provinces were willing to pay the federal government to have it withdraw from the lottery field. But where they right to be concerned? Did Loto-Canada reduce the sales and more importantly the net revenues of provincial lotteries? Table 1 presents data on the sales of provincial and federal lotteries for the 1970-1980 period when provincial lotteries were introduced and the federal lottery existed.

It shows that the size of the Canadian lottery market increased twenty fold from 1970 to 1980 and almost doubled from 1975 to 1976, with the creation of Loto-Canada, as well as the Atlantic and Western Lottery Corporations. This growth was also considerable from 1976 to 1977 . Loto-Canada accounted for almost 30\% of the lottery sales in 1977 and 1978; its introduction was accompanied by the second largest year over year growth in provincial lottery sales in the 1970-1980 period while its demise in 1979 was associated with the strongest year over year growth in overall sales in the 1976/1977 to 1979/1980 years. Hence, looking at these numbers, one cannot easily answer the question posed above. To correctly assess the impact of Loto-Canada on the provincial lotteries, we therefore carry out a multivariate analysis.

Table 1: Ticket sales and ticket sales growth (year over year) by Lottery Corporation and total, 1970-1980

\begin{tabular}{|c|c|c|c|c|c|c|c|c|c|c|c|c|}
\hline & \multicolumn{2}{|c|}{$\begin{array}{c}\text { Atlantic Lottery } \\
\text { Corporation }\end{array}$} & \multicolumn{2}{|c|}{ Loto-Québec } & \multicolumn{2}{|c|}{$\begin{array}{c}\text { Ontario Lottery } \\
\text { Corporation } \\
\end{array}$} & \multicolumn{2}{|c|}{$\begin{array}{c}\text { Western Lottery } \\
\text { Corporation } \\
\end{array}$} & \multicolumn{2}{|c|}{ Loto-Canada } & \multicolumn{2}{|c|}{ Provincial total } \\
\hline & $\begin{array}{c}\text { Ticket } \\
\text { sales (M\$) }\end{array}$ & $\begin{array}{c}\text { Growth } \\
(\%)\end{array}$ & $\begin{array}{c}\text { Ticket } \\
\text { sales (MS) }\end{array}$ & $\begin{array}{c}\text { Growth } \\
(\%)\end{array}$ & $\begin{array}{c}\text { Ticket } \\
\text { sales (M\$) }\end{array}$ & $\begin{array}{c}\text { Growth } \\
(\%)\end{array}$ & $\begin{array}{c}\text { Ticket } \\
\text { sales (M\$) }\end{array}$ & $\begin{array}{c}\text { Growth } \\
(\%)\end{array}$ & $\begin{array}{c}\text { Ticket } \\
\text { sales (M\$) }\end{array}$ & $\begin{array}{c}\text { Growth } \\
(\%)\end{array}$ & $\begin{array}{c}\text { Ticket sales } \\
\text { (M\$) }\end{array}$ & $\begin{array}{c}\text { Growth } \\
(\%)\end{array}$ \\
\hline $\begin{array}{l}1970 \\
\end{array}$ & & & 251436 & & & & & & & & 251436 & \\
\hline 1971 & & & 60495 & 18 & & & & & & & 60495 & 18 \\
\hline 1972 & & & 97164 & 61 & & & & & & & 97164 & 61 \\
\hline 1973 & & & 125510 & 29 & & & & & & & 125510 & 29 \\
\hline 1974 & & & 132185 & 5 & & & & & & & 132185 & 5 \\
\hline 1975 & & & 147892 & 12 & 97137 & & & & & & 245029 & 85 \\
\hline 1976 & 11574 & & 183343 & 24 & 218792 & 125 & 30104 & & 107182 & & 443813 & 81 \\
\hline 1977 & 40602 & 251 & 202899 & 11 & 240431 & 10 & 71273 & 137 & 225214 & 110 & 555205 & 25 \\
\hline 1978 & 43617 & 7 & 244122 & 20 & 235106 & -2 & 129826 & 82 & 258907 & 15 & 652671 & 18 \\
\hline 1979 & 41096 & -6 & 318686 & 31 & 323787 & 38 & 156305 & 20 & 134226 & -48 & 839874 & 29 \\
\hline 1980 & 52557 & 28 & 410554 & 29 & 490333 & 51 & 200225 & 28 & & & 1153669 & 37 \\
\hline
\end{tabular}

Source: Roy and Vaillancourt (2000) and calculations by the authors. 
A literature review (Mikesell and Zorn 1987; Mikesell, 1988; Tosun and Skidmore, 2004) allowed us to identify key variables determining lottery revenues and sales over time. Two important variables are average personal income and the unemployment rate: an increase in both should have a positive impact on sales and thus revenues ${ }^{13}$.

Another variable is the availability of substitutes for lotteries measured here by the annual net benefits obtained by provinces from casinos and video lottery terminals (zero before 1990); it should reduce lottery sales and thus provincial gaming revenues ${ }^{14}$. Finally we use four annual dichotomous variables to account for the presence or not of Loto-Canada. To take into account the underlying demographic and taste differences between provinces we include dichotomous variables for each (no constant term). The regression results are found in Appendix A-2 where various econometric issues are also discussed.

The existence of Loto-Canada has an uncertain impact on provincial lottery sales and more importantly revenues. On one hand, Loto-Canada may grab market shares from the provincial lottery corporations, reducing their sales and revenues. On the other, its promotion of lotteries may increase the overall lottery market and consequently revenues for all suppliers. Our results indicate that the impact of Loto-Canada on provincial lottery sales and benefits was negative for 1978 and 1979. In 1978, the presence of Loto-Canada reduced per capita net benefits growth by $\$ 5.8$ and in 1979 by a comparable $\$ 5.5$. Thus the provinces gained from removing a competitor. Given Canada's population then, and in the absence of Loto-Canada, provincial revenues would have grown by about \$150-175 M more in both years. One may be surprised that we find no such impact for 1976 or 1977. But recall that the Western Lottery Corporation and the Atlantic Lottery Corporation were both created during the first two years in which Loto-Canada was in operation. As shown in table 1 , this was an unsettled gaming market where multiple factors such as new suppliers of lotteries interacted.

\footnotetext{
${ }^{13}$ During recessions when unemployment increases, individuals find buying lottery tickets more attractive due to the greater marginal utility of expected lottery winnings.

${ }_{14}$ There is little inter-provincial sales of lotteries in Canada ; thus this is not accounted for
} 
Thus the payment of $\$ 24 \mathrm{M}$ agreed to in 1979 is less than $20 \%$ of the $150-175 \$ \mathrm{M}$ amount noted above. While one must be careful in comparing a legally set amount to be paid in perpetuity (in real terms) and one obtained from multivariate analysis, it seems quite plausible that the provinces were right from a revenue perspective to purchase exclusivity in the lottery field.

\section{Evaluating the 1979 agreement: a financial perspective}

The preceding analysis shows that provinces were right to buy out the federal government from the lottery field. But did they pay too little or too much? Or reciprocally, did the federal government receive too little or too much? One can answer these questions by examining alternative scenarios given the subsequent evolution of the lottery market and the gaming market as a whole.

The federal/provincial 1979 lottery agreement takes into account only lotteries, which were at the time the only form of legal gaming in Canada. Following the growth that occurs as of 1990 in the casino and video lottery terminals (VLT) field, the proportion of lottery revenues in total provincial gaming revenues has shrunk from 100\% to 34\% in 2010 (see figure 1). Thus, the provincial payments to the federal government, which represented 3 percent of provincial gaming revenues in the late 1980s, have been reduced to approximately 1 percent in $2010^{15}$. In light of these developments, it is interesting to estimate the revenues that the federal government would have received if the 1979 agreement had been a different one. We examine five possible alternatives.

\footnotetext{
${ }^{15}$ These \% were calculated by the authors using data from Roy and Vaillancourt for 1980 and from annual reports by provincial gaming body for 2010
} 
Figure 1: Lottery and gaming payments by gaming authorities to provincial governments, 1969-2010, nominal \$ 000

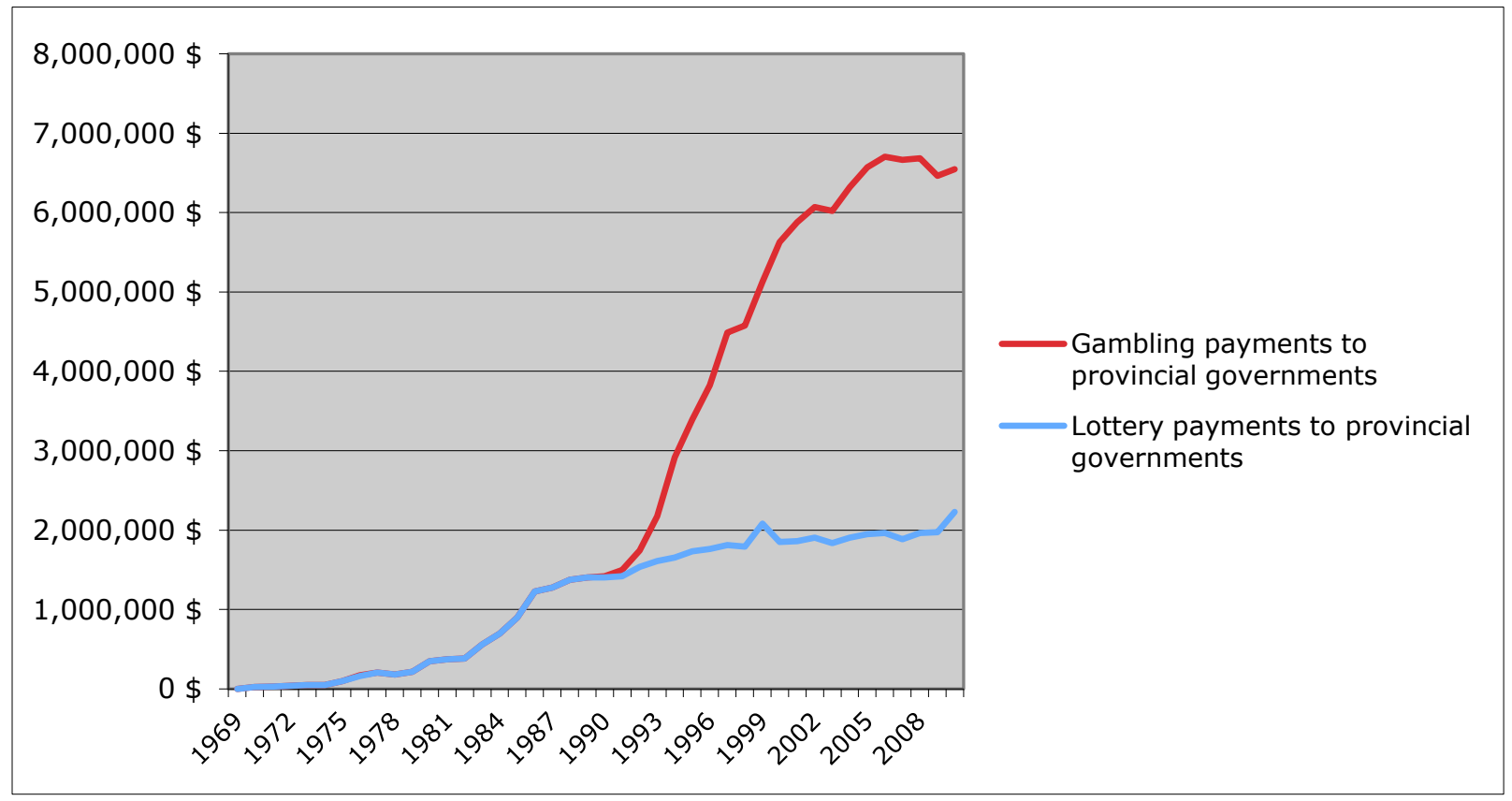

Source: calculations by the authors using data from Roy and Vaillancourt (2000) and from gaming bodies

1) The 7\% solution - provincial payments to the federal government/provincial gaming revenues

In 1980 - the first year of the federal/provincial lottery agreement - the payments to the federal government amounted to $\$ 26.5$ million, which represented at the time $7 \%$ of the gaming revenues of provincial governments. This ratio has constantly decreased since then, reaching $1.02 \%$ in 2010. If the agreement had provided that the federal government be paid a fixed percentage of the provincial gaming revenues, these payments to the Canadian government would have taken into account VLT and casino revenues when they were introduced in the 1990s. If we use the federal market share of $7 \%$ associated with the first direct payment in 1980, we find that federal government gaming revenues would have amounted to $\$ 464.9$ million in 2010 , compared to the actual amount of $\$ 66.6$ million the federal received for the same year - i.e. revenues would have been 7 times higher. 
2) The $25 \%$ solution (large) - The 1978 federal share of the gaming market

Even more striking are the simulation results if we assume that the agreement had provided that the federal government maintains its 1978 market share of the government gaming revenues (25\%), then limited to lotteries. We calculate that the federal government would have received gaming revenues of $\$ 1,663.3$ million in 2010 .

3-4) The $25 \%$ solution (narrow) - The 1978 federal share of the lottery market

Even if the federal government had agreed to a fixed percentage applicable strictly on provincial lottery revenues (i.e. excluding casino and VLT revenues), it would have received considerably higher payments than the effective ones. Indeed, in 2010, a 7 and a 25 percent share solely applicable to lottery revenues would have respectively yielded the federal government $\$ 158.3$ and $\$ 566.3$ million.

5) The 14\% solution - The 1979 federal share of ticket sales (net of costs)

Another possibility is linking the provincial payments to the gross revenues associated with ticket sales. For instance, in 1979, Loto-Canada's ticket sales amounted to $\$ 134.2$ million, whereas the sum of the provincial sales was $\$ 839.9$ million. That is, 14 percent of lottery tickets sales were sold by the federal lottery corporation. Had this percentage been applied to subsequent provincial ticket sales net of the costs of a lottery corporation ${ }^{16}$ to calculate federal payments, they would have amounted to \$288 million in 2010.

The results from these various simulations are found in figure $2^{17}$ and appendix table A-3.

\footnotetext{
${ }^{16}$ We projected those costs by using the 1979 provincial net benefits/ticket sales ratio of 26 percent

${ }^{17}$ Except the 25\% ( large) results whose inclusion make the figure illegible
} 
Figure 2: Effective federal lottery payments and simulated payments indexed to 1978 and 1980 federal lottery market share, 1979 share of ticket sales less administrative costs and 1980 federal gaming market share, 1980-2010 \$000 nominal terms

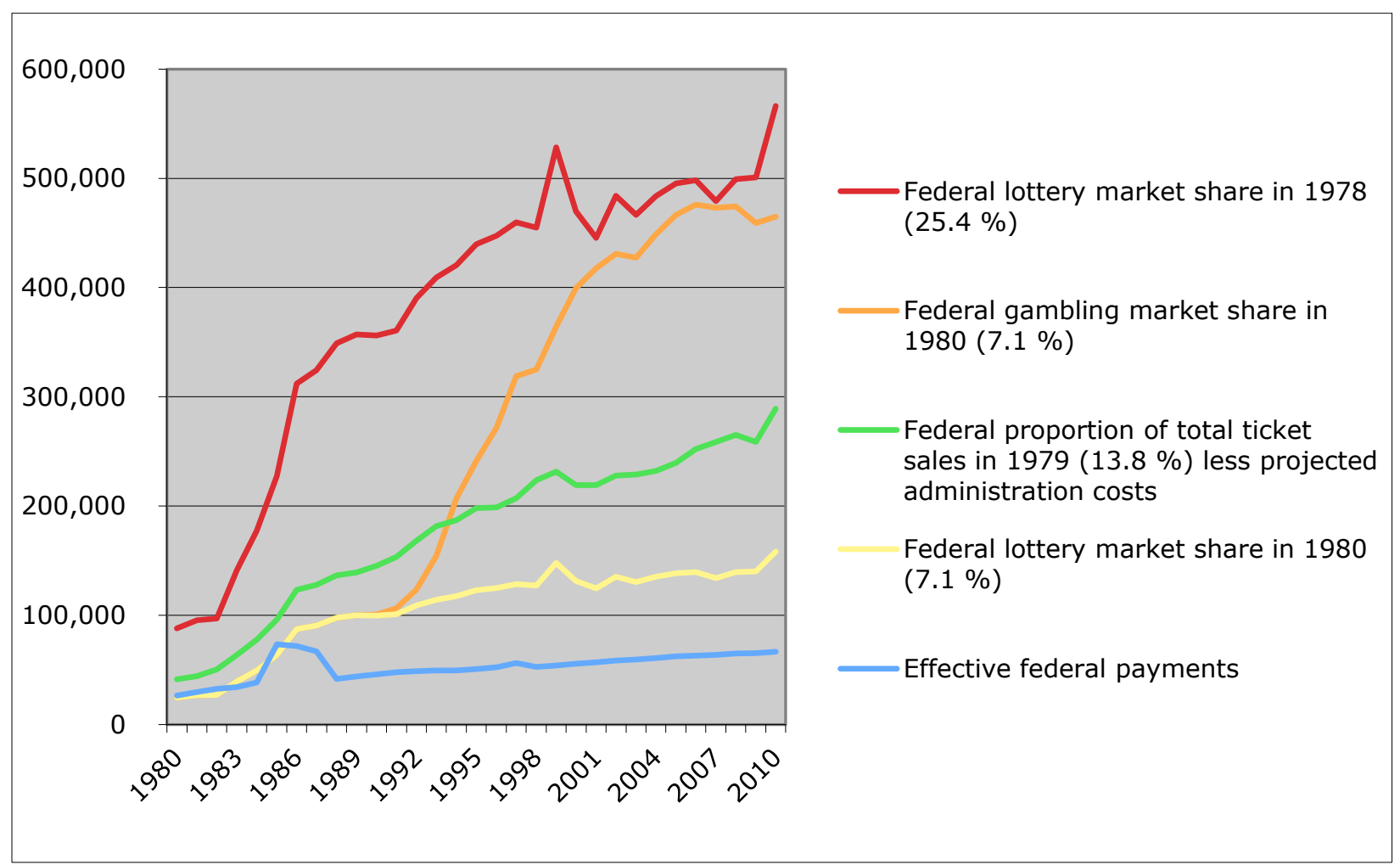

Source: table A-3

Thus, because of the considerable growth of the Canadian lottery and gaming markets since 1980, the agreement of 1979 is not very generous to the federal government. At least five alternative formulas would have been more beneficial to the federal government; the formula that was actually used was incapable of taking into account either the future growth of the lottery market or the diversification of the gaming market in Canada from 1980 to 2010 , let alone both.

\section{Conclusion}

This paper presents an unusual feature of inter-governmental financial relations: a payment by constituent units of a federation to the federal government to keep it out of a fiscal field and thus gain sole occupancy for themselves. It reviews how this agreement came about and shows that the federal presence through Loto-Canada did reduce provincial gaming revenues from lotteries and thus supports the provinces' objection to the federal 
government remaining an active player in the lottery market. This, given the payment formula agreed to, has turned out to be quite advantageous for the provinces. This agreement shows an original, and as far as we know, fairly unique way to settle the sharing of a tax field between different levels of government in a federation. It is in a sense a mirror image of the federal provincial Tax Rental Agreements of WWII when the federal government paid the provinces to obtain temporary sole occupancy of the income (corporate and individual) and succession tax fields. These agreements morphed into the current system of shared tax fields and equalization payments. This lottery agreement has remained frozen (in real \$) in time. 


\section{Appendix 1 - Key features of the 1978 and 1979 federal provincial agreements on the gaming tax field}

\section{8 agreement}

- Pricing agreement: tickets costing $\$ 9$ or $<$ sold by the provincial lotteries, $\$ 10+$ by the federal lottery.

- Pay out by each lottery of no more than $50 \%$ of gross revenues and marketing expenses of no more than $4 \%$ of such revenues.

- Lotteries with a price of $\$ 5+$ must not have more than one draw per month.

- Lotteries are those of a type similar to those currently operated.

- Monetary limits to be reviewed every five years.

- Revenue sharing to be envisaged: $12,5 \%$ of federal revenues and $3 \%$ of provincial revenues could be used for projects of a national or international significance.

- The federal, Ontario and Québec governments must reach a reasonable agreement on how to dispose of Loto Select.

\section{9 agreement}

- Loto-Canada to be closed as soon as possible

- Yearly payment by provinces amounting to $\$ 24$ million from the provincial lottery corporations. These payments took the form of quarterly instalments of $\$ 6$ million, beginning as of April 1st 1980, and were planned to increase according to inflation, using the Consumer Price Index as a measure. Sharing between provinces to be decided by them.

- Promised funding for hockey arenas renovations in Alberta, Manitoba and Québec now to be paid by these provinces while the Ontario Royal Museum will not receive federal funding.

- Ontario and Québec will finalize payments linked to the dismantling of Loto Select. 
Appendix 2 Regression results

To estimate the effect of the presence of Loto-Canada on the provinces' revenues, we use the following model:

Provincial Lottery Revenues OR Ticket Sales $=\beta_{1}$ Income $_{t}+\beta_{2}$ Unemployment $_{t-1}+$ $\beta_{3}$ Alternative Gambling $+\beta_{5} L C 1976+\beta_{6} L C 1977+\beta_{7} L C 1978+\beta_{8} L C 1979+\beta_{9}$ Year $+\beta_{10}$ Provincial Dummies

All continuous variables, namely Provincial Revenues, Ticket Sales, Unemployment, Income and Alternative Gaming are used in both level and first-difference form. LC1976 through LC1979 are dummy variables designating the presence of Loto-Canada in the lottery fiscal

field during those four years. Income and Unemployment are respectively the average personal income and the annual unemployment rate. The inclusion of both the current and lagged value of unemployment allows the effect of that variable to take place over a longer period of time.

The Provincial variables are dummies used to extract the provincial fixed effects. They refer to the Canadian lottery corporations, namely the Atlantic Lottery Corporation, Loto-Québec, the Western Lottery Corporation, and the Ontario Lottery Corporation. The model includes no constant term so all four provincial dummies are present. These fixed-effects variables are expected to capture the province-specific factors that may affect the dependent variables, such as cultural factors and attitudes towards gaming. For instance, Quebec is known to have a longer history of gaming. Another such factor is the composition of the population. Demographic variables such as age, sex and education have an impact on the purchase of lottery tickets (Roy and Vaillancourt, 2000).

\section{Data}

Our set of data goes from 1969 to 2010 and comes from five lottery corporations: the Atlantic Lottery Corporation (ALC), Loto-Québec (LQ), the Ontario Lottery and Gaming 
Corporation (OLG), the Western Lottery Corporation (WLC) and the British Columbia Lottery Corporation (BCLC). Data from the WLC and BCLC were combined to form one data set (referred to in the results as WBC). Before 1985, the British Columbia lottery market was managed by the WLC. For uniformity purposes, we disregard the later split when British Columbia decided to create its own lottery corporation. We use those 147 panel observations in our regression.

Provincial lottery net benefits, lottery ticket sales and provincial non-traditional lottery and gaming net benefits (henceforth referred to as alternative gaming) are found in Vaillancourt and Roy (2000); more recent numbers were collected directly from the annual reports of the five lottery corporations. Alternative gaming revenue of the WLC provinces was gathered from annual reports of those provinces' gaming commissions; non-traditional lottery and other forms of gaming activity are administered independently in those provinces. These are the Saskatchewan Liquor and Gaming Authority, the Manitoba Lotteries Corporation and the Alberta Gaming and Liquor Commission. We used population data from Statistics Canada (CANSIM table 051-0005) to calculate the per capita net benefits of provincial lotteries and lottery ticket sales. The average personal income data was also provided by Statistics Canada (CANSIM table 380-0050). We aggregated information from Nova Scotia, Newfoundland, New Brunswick and Prince Edward's Island to form the ALC observations, and that from British Columbia, Alberta, Saskatchewan and Manitoba for WBC observations.

We estimated three equations for two dependent variables:

1) A level equation with logarithmic variables; 2) a first difference equation with the same variables and lastly 3) a first difference equation with a supplementary variable-lagged unemployment.

The level equation displayed strong autocorrelation stemming from the non-stationarity of unemployment but we report it as it is the traditional estimation in this field of work; the very high coefficients of determination (over 0.99 ) strongly suggest a spurious regression. 
Taking the first difference of our continuous variables implies that we investigate shortterm movements i.e. the impact of Loto-Canada on the annual growth of provincial revenues and ticket sales.

\section{Estimation results}

Interpretation will be limited to the coefficients from the final specification, first differences with the lagged value of unemployment. Estimates from the other specifications are presented in the table below but will not be discussed.

The observations used in the final regression being first differences, the estimated coefficients represent the impact of the growth of right hand side variables on the short term variations of the dependent variables. We observe at first that the R-squared values demonstrate a relatively good fit on the regressions. For a first-difference regression, a value of 0.33 for net benefits and 0.35 for ticket sales suggest that the independent variables explain a significant portion of the observed variations in lottery profits and ticket sales. The model seems reasonably well suited to explain fluctuations in the lottery market.

Unemployment exhibits an interesting impact on the lottery market. Whereas the lagged value does show the positive effect on net benefits and ticket sales that we predicted, a contemporaneous change in unemployment is observed to cause a decrease in those same measures. Our estimates predict that a rise of 1 percent in the unemployment rate in this period diminishes the growth of net benefits per capita by $\$ 1.75$ and ticket sales by $\$ 2.90$ (respective averages are $\$ 41.85$ and $\$ 144.11$ ). On the other hand, the same change in unemployment causes lottery benefits to rise by $\$ 0.98$ and ticket sales by $\$ 3.10$ in the next period. Changes in income per person, on the other hand, reveal neither statistically or economically significant estimates for the ticket sales regression. The coefficient on income for the net benefits regression is statistically significant at the $10 \%$ level. It shows that the growth of net benefits is reduced by $\$ 0.001$ in the event of a rise of $\$ 1$ in mean income per person. Alternative gaming revenues display the expected negative impact on the lottery market. As other forms of gaming (video lotteries, casinos, etc.) can be viewed as substitutes to lottery purchases, it is normal to expect a decrease in demand for traditional 
lottery if other forms of gaming expand. We observe that a rise of $\$ 1$ in alternative gaming revenues lowers the growth of net benefits by $\$ 0.17$ and ticket sales by $\$ 0.20$. The intercepts represent the time-invariant differences that distinguish the lottery markets in different provinces, in other words the provincial fixed effects. It appears, however, that those fixed effects have little influence over the two dependent variables. The only intercepts whose equality can be rejected at the $10 \%$ threshold are those of LQ and WBC in the net benefits regression. Their prediction is that if all else remains constant, WBC net benefits will grow by an additional $\$ 2$ each period compared to LQ net benefits. 
Table A-1: OLS fixed-effect estimates of three different specifications on the dependent variables of Per Capita Provincial Lottery Net Benefits and Provincial Lottery Ticket Sales, 1969-2010.

\begin{tabular}{|c|c|c|c|c|c|c|}
\hline & \multicolumn{3}{|c|}{ Provincial Gaming Revenues } & \multicolumn{3}{|c|}{ Ticket Sales } \\
\hline & $\begin{array}{c}\text { Level } \\
\text { Logarithmic } \\
\text { specification }\end{array}$ & $\begin{array}{c}\text { First } \\
\text { difference }\end{array}$ & $\begin{array}{c}\text { First difference } \\
\text { w/ lagged } \\
\text { unemployment }\end{array}$ & $\begin{array}{c}\text { Level } \\
\text { Logarithmic } \\
\text { specification }\end{array}$ & $\begin{array}{c}\text { First } \\
\text { difference }\end{array}$ & $\begin{array}{c}\text { First difference } \\
\text { w/lagged } \\
\text { unemployment }\end{array}$ \\
\hline Unemployment & $\begin{array}{l}0.380 * * \\
(-0.175) \\
\end{array}$ & $\begin{array}{l}-1.441^{*} \\
(-0.391) \\
\end{array}$ & $\begin{array}{l}-1.751^{*} \\
(-0.405) \\
\end{array}$ & $\begin{array}{c}0.306^{* *} \\
(0.139) \\
\end{array}$ & $\begin{array}{c}-1.995^{* *} \\
(0.983) \\
\end{array}$ & $\begin{array}{l}-2.903^{*} \\
(1.005) \\
\end{array}$ \\
\hline Income & $\begin{array}{c}2.078^{*} \\
(-0.234)\end{array}$ & $\begin{array}{c}-0.002^{* *} \\
(-0.001)\end{array}$ & $\begin{array}{c}-0.001^{* * *} \\
(-0.001)\end{array}$ & $\begin{array}{l}2.436^{*} \\
(0.185)\end{array}$ & $\begin{array}{l}-0.001 \\
(0.002)\end{array}$ & $\begin{array}{c}0.000 \\
(0.002)\end{array}$ \\
\hline $\begin{array}{l}\text { Alternative } \\
\text { gaming }\end{array}$ & $\begin{array}{c}0.039 \\
(-0.034)\end{array}$ & $\begin{array}{l}-0.178^{*} \\
(-0.041) \\
\end{array}$ & $\begin{array}{l}-0.168^{*} \\
(-0.041)\end{array}$ & $\begin{array}{l}0.074^{*} \\
(0.027)\end{array}$ & $\begin{array}{c}-0.236^{* *} \\
(0.102)\end{array}$ & $\begin{array}{c}-0.204^{* *} \\
(0.1)\end{array}$ \\
\hline Ic1976 & $\begin{array}{l}-0.076 \\
(-0.229)\end{array}$ & $\begin{array}{l}-0.384 \\
(-3.147)\end{array}$ & $\begin{array}{l}-3.301 \\
(-4.398)\end{array}$ & $\begin{array}{l}-0.193 \\
(0.182)\end{array}$ & $\begin{array}{l}-1.120 \\
(7.917)\end{array}$ & $\begin{array}{l}-10.319 \\
(10.916)\end{array}$ \\
\hline Ic1977 & $\begin{array}{c}-0.131 \\
(-0.199) \\
\end{array}$ & $\begin{array}{c}-0.481 \\
(-2.629) \\
\end{array}$ & $\begin{array}{c}-1.376 \\
(-3.137) \\
\end{array}$ & $\begin{array}{l}-0.082 \\
(0.158) \\
\end{array}$ & $\begin{array}{l}-2.961 \\
(6.616) \\
\end{array}$ & $\begin{array}{l}-5.025 \\
(7.786) \\
\end{array}$ \\
\hline Ic1978 & $\begin{array}{c}-0.350 * * * \\
(-0.197)\end{array}$ & $\begin{array}{l}-4.647^{* *} \\
(-2.266)\end{array}$ & $\begin{array}{l}-5.814^{* *} \\
(-2.615)\end{array}$ & $\begin{array}{l}-0.080 \\
(0.156)\end{array}$ & $\begin{array}{l}-7.296 \\
(5.701)\end{array}$ & $\begin{array}{c}-12.688^{* * *} \\
(6.49)\end{array}$ \\
\hline Ic1979 & $\begin{array}{l}-0.456 * * \\
(-0.196) \\
\end{array}$ & $\begin{array}{c}-4.856^{* *} \\
(-2.294) \\
\end{array}$ & $\begin{array}{l}-5.513 * * \\
(-2.292) \\
\end{array}$ & $\begin{array}{l}-0.082 \\
(0.155) \\
\end{array}$ & $\begin{array}{l}-7.121 \\
(5.773) \\
\end{array}$ & $\begin{array}{l}-8.975 \\
(5.688) \\
\end{array}$ \\
\hline $\begin{array}{l}\text { Time } \\
\text { trend }\end{array}$ & $\begin{array}{l}-0.044^{*} \\
(-0.016)\end{array}$ & $\begin{array}{l}-0.126^{*} \\
(-0.039)\end{array}$ & $\begin{array}{l}-0.133^{*} \\
(-0.039)\end{array}$ & $\begin{array}{l}-0.059^{*} \\
(0.013)\end{array}$ & $\begin{array}{c}-0.246^{* *} \\
(0.097)\end{array}$ & $\begin{array}{l}-0.258^{*} \\
(0.097)\end{array}$ \\
\hline$A L C$ & $\begin{array}{c}-17.174 * \\
(-1.906)\end{array}$ & $\begin{array}{l}5.728^{*} \\
(-1.208)\end{array}$ & $\begin{array}{l}5.484^{*} \\
(-1.233)\end{array}$ & $\begin{array}{c}-18.885^{*} \\
(1.51)\end{array}$ & $\begin{array}{l}14.402 * \\
(3.038)\end{array}$ & $\begin{array}{c}13.535^{*} \\
(3.06)\end{array}$ \\
\hline$L Q$ & $\begin{array}{c}-16.750^{*} \\
(-1.926) \\
\end{array}$ & $\begin{array}{c}5.193^{*} \\
(-1.069) \\
\end{array}$ & $\begin{array}{l}5.193^{*} \\
(-1.113) \\
\end{array}$ & $\begin{array}{c}-18.763^{*} \\
(1.526) \\
\end{array}$ & $\begin{array}{c}10.831^{*} \\
(2.69) \\
\end{array}$ & $\begin{array}{l}10.606^{*} \\
(2.763) \\
\end{array}$ \\
\hline OLG & $\begin{array}{l}-17.121^{*} \\
(-1.985)\end{array}$ & $\begin{array}{c}6.015^{*} \\
(-1.223) \\
\end{array}$ & $\begin{array}{l}5.783^{*} \\
(-1.253)\end{array}$ & $\begin{array}{c}-19.213^{*} \\
(1.573)\end{array}$ & $\begin{array}{l}12.911^{*} \\
(3.078)\end{array}$ & $\begin{array}{l}12.013^{*} \\
(3.109)\end{array}$ \\
\hline$W B C$ & $\begin{array}{l}-17.241^{*} \\
(-1.983)\end{array}$ & $\begin{array}{l}7.458^{*} \\
(-1.3)\end{array}$ & $\begin{array}{l}7.182^{*} \\
(-1.335)\end{array}$ & $\begin{array}{c}-19.283^{*} \\
(1.571)\end{array}$ & $\begin{array}{l}13.942 * \\
(3.272)\end{array}$ & $\begin{array}{l}12.683^{*} \\
(3.312)\end{array}$ \\
\hline $\begin{array}{c}\text { Lagged } \\
\text { unemployment }\end{array}$ & & & $\begin{array}{l}0.980^{* *} \\
(-0.393) \\
\end{array}$ & & & $\begin{array}{l}3.055^{*} \\
(0.975) \\
\end{array}$ \\
\hline$R$-squared & 0.9902 & 0.3251 & 0.3516 & 0.9965 & 0.3460 & 0.3855 \\
\hline
\end{tabular}

Source: calculations by the authors

* indicates significance at the $1 \%$ threshold

** indicates significance at the $5 \%$ threshold

*** indicates significance at the $10 \%$ threshold 


\section{Appendix 3 - Table of effective provincial payments and simulated payments under five scenarios, lottery market and gaming market, 1980-2010, nominal \$000}

\begin{tabular}{|c|c|c|c|c|c|c|}
\cline { 5 - 7 } \multicolumn{2}{l}{} & \multicolumn{2}{c|}{$\begin{array}{c}\text { Traditional lottery } \\
\text { market }\end{array}$} & $\begin{array}{c}\text { Overall gaming } \\
\text { market }\end{array}$ \\
\hline Year & $\begin{array}{c}\text { Effective } \\
\text { Provincial } \\
\text { payments }\end{array}$ & $\begin{array}{c}14 \% \\
\text { solution }\end{array}$ & $\begin{array}{c}7 \% \\
\text { solution }\end{array}$ & $\begin{array}{c}25 \% \\
\text { solution }\end{array}$ & $\begin{array}{c}7 \% \\
\text { solution }\end{array}$ & $\begin{array}{c}25 \% \\
\text { solution }\end{array}$ \\
\hline 1980 & 26515 & 41234 & 24617 & 88065 & 24617 & 88065 \\
\hline 1981 & 29592 & 44231 & 26634 & 95281 & 26634 & 95281 \\
\hline 1982 & 32457 & 50469 & 27137 & 97081 & 27137 & 97081 \\
\hline 1983 & 34124 & 63751 & 39547 & 141478 & 39547 & 141478 \\
\hline 1984 & 38359 & 77615 & 49554 & 177279 & 49554 & 177279 \\
\hline 1985 & 73321 & 96203 & 63631 & 227636 & 63631 & 227636 \\
\hline 1986 & 71753 & 123438 & 87201 & 311959 & 87201 & 311959 \\
\hline 1987 & 67062 & 127799 & 90646 & 324284 & 90646 & 324284 \\
\hline 1988 & 41656 & 136497 & 97553 & 348992 & 97553 & 348992 \\
\hline 1989 & 43869 & 139063 & 99854 & 357223 & 99854 & 357223 \\
\hline 1990 & 45972 & 145359 & 99548 & 356128 & 100643 & 360046 \\
\hline 1991 & 47944 & 153280 & 100802 & 360616 & 106421 & 380719 \\
\hline 1992 & 48736 & 168256 & 109105 & 390321 & 123580 & 442103 \\
\hline 1993 & 49423 & 181448 & 114343 & 409059 & 154453 & 552550 \\
\hline 1994 & 49604 & 187222 & 117513 & 420399 & 207136 & 741022 \\
\hline 1995 & 50720 & 198109 & 122923 & 439754 & 241085 & 862472 \\
\hline 1996 & 52223 & 198743 & 125041 & 447330 & 271500 & 971283 \\
\hline 1997 & 56158 & 207017 & 128501 & 459709 & 318731 & 1140249 \\
\hline 1998 & 52773 & 223747 & 127136 & 454823 & 324877 & 1162234 \\
\hline 1999 & 54002 & 231473 & 147734 & 528512 & 364106 & 1302576 \\
\hline 2000 & 55589 & 219202 & 131272 & 469622 & 399623 & 1429639 \\
\hline 2001 & 56786 & 219166 & 132161 & 445368 & 417487 & 1493546 \\
\hline 2002 & 58383 & 227907 & 135339 & 484170 & 431021 & 1541962 \\
\hline 2003 & 59571 & 228929 & 130431 & 466611 & 427485 & 1529312 \\
\hline 2004 & 60626 & 232134 & 135217 & 483734 & 448698 & 1605203 \\
\hline 2005 & 62349 & 239509 & 138450 & 495300 & 466663 & 1669472 \\
\hline 2006 & 63125 & 252312 & 139313 & 498386 & 475867 & 1702399 \\
\hline 2007 & 63772 & 258604 & 133911 & 479063 & 473155 & 1692696 \\
\hline 2008 & 65143 & 265240 & 139535 & 499180 & 474423 & 1697232 \\
\hline 2009 & 65330 & 258615 & 139971 & 500741 & 458935 & 1641825 \\
\hline 2010 & 66577 & 288983 & 158295 & 566294 & 464930 & 1663272 \\
\hline
\end{tabular}

Source : calculations by the authors 


\section{Bibliography}

BIRD, $\mathrm{R}$ and $\mathrm{F}$ Vaillancourt "'Reconciling Diversity with Equality: The Role of Intergovernmental Fiscal Arrangements in Maintaining an Effective State in Canada" in Fiscal Fragmentation in Decentralized Countries (R. Bird and R. Ebel Ed) Northampton: Edward Elgar, 2007, p 49-88

COUSINEAU, Guy, "Report on Loto Select", Parliament Public Archives, Sessional papers, 304$7 / 13$.

MIKESELL, John L., "State lottery sales and economic activity", National Tax Journal 41 No. 1 (March 1988): 165-171

MIKESELL, John L., and Kurt C. Zorn, "State Lottery Sales: Separating the influence of Markets and Game Structure", Growth and Change 18 No. 4(Fall 1987): 10-19

ROY, Alexandre, and François Vaillancourt, "Gambling and Governments in Canada, 19691998: How Much? Who Plays? What Payoff?", Special studies in taxation and public finance No. 2, Canadian Tax Foundation (2000): 72 p.

SERKAN TOSUN, Mehmet, and Mark Skidmore, "Interstate Competition and State Lottery Revenues", National Tax Journal 57 No. 2 (June 2004) : 163-178 